\title{
Causality between CO2 Emissions and Stock Markets
}

\author{
Chia-Lin Chang 1,2@, Jukka Ilomäki ${ }^{3}$, Hannu Laurila ${ }^{3}$ and Michael McAleer $2,4,5,6,7, *$ (D) \\ 1 Department of Applied Economics and Department of Finance, National Chung Hsing University, \\ Taichung City 402, Taiwan; changchialin@email.nchu.edu.tw \\ 2 Department of Finance, Asia University, Wufeng District, Taichung City 41354, Taiwan \\ 3 Faculty of Management and Business, Tampere University, FI-33014 Tampere, Finland; \\ jukka.ilomaki@tuni.fi (J.I.); hannu.laurila@tuni.fi (H.L.) \\ 4 Discipline of Business Analytics, University of Sydney Business School, Darlington, NSW 2006, Australia \\ 5 Econometric Institute, Erasmus School of Economics, Erasmus University Rotterdam, \\ 3062 PA Rotterdam, The Netherlands \\ 6 Department of Economic Analysis and ICAE, Complutense University of Madrid, 28040 Madrid, Spain \\ 7 Institute of Advanced Sciences, Yokohama National University, Kanagawa 240-8501, Japan \\ * Correspondence: michael.mcaleer@gmail.com
}

Received: 6 May 2020; Accepted: 31 May 2020; Published: 5 June 2020

\begin{abstract}
It is generally accepted in the scientific community that carbon dioxide (CO2) emissions, which lead to global warming, arise from using fossil fuels, namely coal, oil and gas, as energy sources. Consequently, alleviating the effects of global warming and climate change necessitates substantial reductions in the use of fossil fuel energy. This paper uses a financial market-based approach to investigate whether positive stock returns cause changes in $\mathrm{CO} 2$ emissions, or vice-versa, based on the Granger causality test to determine cause and effect, or leader and follower. If Granger causality can be determined in any direction, this will enable a clear directional statement regarding temporal predictability between stock returns and $\mathrm{CO} 2$ emissions. The empirical data include annual $\mathrm{CO} 2$ emissions from fuel combustion of the three main fossil energy sources, namely coal, oil and gas, based on 18 countries with sophisticated financial markets that are in the Morgan Stanley Capital International (MSCI) World Index from 1971 to 2017. The empirical results show clearly that all the statistically significant causality findings are unidirectional from the stock market returns to $\mathrm{CO} 2$ emissions from coal, oil and gas, but not the reverse. More importantly, the regression results suggest that when stock returns rise by $1 \%, \mathrm{CO} 2$ emissions from coal combustion decrease by $9 \%$ among the countries that are included in MSCI World Index. Furthermore, when stock returns rise 1\%, CO2 emissions from oil combustion increase by $2 \%$, but stock returns have no significant effect on $\mathrm{CO} 2$ emissions from gas combustion.
\end{abstract}

Keywords: global warming; climate change; carbon emissions; fossil fuels; sophisticated financial markets; stock market returns; Granger causality; predictability

\section{Introduction}

Climate change scientists generally agree that carbon dioxide $(\mathrm{CO} 2)$ emissions, which lead to global warming, arise from using fossil fuels, namely coal, oil and gas, as energy sources. In this scenario, alleviating the effects of global warming and climate change necessitates substantial reductions in the use of fossil fuel energy. This is one of the most pressing demands on the international community to protect the global environment.

McCollum et al. note that global clean energy investments should exceed fossil fuel energy investments by 2025 in order to meet the Paris Agreement [1,2], which aims to hold the global average temperature growth below $2{ }^{\circ} \mathrm{C}$ compared with the preindustrial environment. Furthermore, 
McCollum et al. warn that, if the prices of crude oil are low in the decades ahead, the chances of mitigating global warming will also be low [3]. Staples et al. argue that greenhouse gases would diminish by $9-68 \%$ if fossil fuels were to be replaced by bioenergy sources in heating and electricity production [4].

Mitigating global warming requires scientists and social scientists of all persuasions to concentrate on reducing carbon emissions. Much of climate change scientific research relies on science and engineering. Useful contributions can also arise from an economic and financial market-based approach to tackling the problem of carbon emissions that would focus on examining the causality from stock market returns to $\mathrm{CO} 2$ emissions arising from fossil fuels. Such an approach would require a negative correlation between stock market returns and $\mathrm{CO} 2$ emissions. Such a negative effect would encourage financial decisions that contribute to higher stock returns and lower $\mathrm{CO} 2$ emissions, as compared with lower stock returns and higher $\mathrm{CO} 2$ emissions.

In a study of 22 developing countries, Sadorsky obtained a positive relationship between stock market growth and the demand for energy [5]. Furthermore, several studies have reported that increases in energy demand tends to increase CO2 emissions (see, for example, [6-8]). However, Paramati et al. examined the relationship between stock market growth and energy production from renewable sources in G20 countries from 1991 to 2012, and found that using renewable energy sources reduced $\mathrm{CO} 2$ emissions and increased economic output [9].

Brockway et al. reported that the fossil fuel return-on-investment ratios are likely to approach those of renewable energy, since exploring new sources tends to be more expensive [10]. Moreover, Egli et al. found that the upfront costs for solar and wind energy production have fallen significantly in Germany over the last 18 years [11]. King and van den Bergh argued that the use of solar and wind energies had to increases two to three times faster than at present in order to maintain the current yearly energy supply growth rate of $0.5 \%$ [12].

Wilson and Staffell noted that the British policy of replacing coal combustion with gas combustion has lowered total CO2 emissions in the UK by 6\% in 2016 alone [13]. Rinscheid and Wustenhagen stated that Germany's recent decision to eliminate coal combustion by 2038 is far below the apparent expectations of the German public [14].

In this paper, we use a financial market-based approach to investigate whether positive stock returns cause changes in $\mathrm{CO} 2$ emissions, or vice-versa. In determining which factor is the leader (cause) and which is the follower (effect), we will use the Granger test $[15,16]$ of (non-)causality. If Granger causality can be determined in any direction, this will enable a clear directional statement regarding temporal predictability between stock returns and $\mathrm{CO} 2$ emissions.

The connection between financial development and carbon emissions has been less discussed and analyzed. For example, Shahbaz et al. examined bidirectional causality between financial development and CO2 emissions in Malaysia from 1971 to 2011 [17]. Omri found bidirectional causality between energy consumption and CO2 emissions for several developing countries for the period 1990-2011 [18]. Ren et al. discovered unidirectional causality from financial investments to $\mathrm{CO} 2$ emissions in China from 2000 to 2010 [19]. Su et al. showed a similar result between Chinese GDP and CO2 emissions from 1992 to 2010 [20].

A reason why financial development could lead to the rise of $\mathrm{CO} 2$ emissions is that financial development is related to the industrial structure, and CO2 emissions are also closely related to the industrial structure. Pertinent recent research on this topic has been conducted by $\mathrm{Xu}$ and Huang [21] regarding spatial research on the effect of the financial structure on $\mathrm{CO} 2$ emissions; by Zhao and Yang [22] on whether financial development influences $\mathrm{CO} 2$ emissions in Chinese provinces; by Tamazian, Chousa and Vadlamannati (2009) on the effects of higher economic and financial development on environmental degradation in BRIC countries [23]; by Jalil and Feridun (2011) on the impact of growth, energy and financial development on the environment in China [24]; by Zhang (2011) on the impact of financial development on carbon emissions in China [25]; by Ozturk and Acaravci (2013) on the long-run and causal analysis of energy, growth, openness and financial development on 
carbon emissions in Turkey [26]; by Haseeb, Xia, Baloch, and Abbas (2018) on financial development, globalization, and CO2 emission in the presence of the environmental Kuznets curve for BRICS (Brazil, Russia, India, China, and South Africa) countries [27]; by Ahmad, Khan, Rahman and Khan (2018) on whether financial development asymmetrically affects $\mathrm{CO} 2$ emissions in China based on the NARDL model [28]; by Boutabba (2014) on the impact of financial development, income, energy and trade on carbon emissions in India [29]; by Xiong, Tu and Ju (2017) on reconciling regional differences in financial development and carbon emissions using a dynamic panel data approach [30]; and by Huang and Zhao (2018) on the impact of financial development on trade-embodied carbon dioxide emissions in Chinese provinces [31].

Although not examining carbon emissions, Ziaei (2015) found that stock market returns had a unidirectional and positive effect on energy consumption while, as above [32], Tamazian et al. (2009) investigated the relationship between stock markets and CO2 emissions in BRIC countries from 1992 to 2004 [23]. They concluded that the development of financial systems tended to reduce CO2 emissions per capita in developing countries.

To the best of our knowledge, this paper is the first to investigate the relationship between stock market returns and carbon emissions for developed economies with sophisticated financial markets. The primary purpose of the paper is to examine the existence of a negative correlation between stock returns and carbon emissions arising from carbon emissions from fossil fuels, and to test for causality between stock returns and carbon emissions. In order to examine further connections between $\mathrm{CO} 2$ emissions and stock returns, we use three regressions with the whole data set to detect the sign of the causality and statistical significance, namely the relative changes in emissions from coal and stocks, oil and stocks, and gas and stocks.

The remainder of the paper is organized as follows: the data and methodology are discussed in Section 2, the empirical results are evaluated in Section 3, and some concluding remarks are presented in Section 4.

\section{Data and Methodology}

The empirical data include annual $\mathrm{CO} 2$ emissions from fuel combustion of the three main fossil energy sources, namely coal, oil and gas. The CO2 emissions data are obtained from the [33] International Energy Agency (IEA) (2020), which provides reliable data of greenhouse gases arising from energy production. The annual reference data come from stock markets, where the focus is on countries with sophisticated financial markets that are included in the Morgan Stanley Capital International (MSCI) World Index from 1971 to 2017.

In addition to data for the world and Europe, the 18 countries in the data set include the USA, Canada, Australia, Japan, Austria, Belgium, France, Denmark, Germany, Italy, The Netherlands, Norway, Spain, Sweden, Switzerland, UK, Singapore and Hong Kong. Thus, we use 20 annual time series with 47 observations of $\mathrm{CO} 2$ emissions (in million tons) from the combustion of coal, oil and gas. The annual MSCI price ratings are reported in US dollars, with dividends reinvested.

The country variables and an aggregate variable, namely the MSCI World Index, are presented in Table 1. The CO2 emissions from three fossil fuels are given in millions of tons, and the MSCI stock index (large and mid-cap) prices with dividends reinvested are in US dollars.

Table 1. Definitions of variables.

\begin{tabular}{cccc}
\hline Variables & Fuel Combustion and Stock Index (Annual) & Source \\
\hline CO2 emissions from coal (Coal) & CO2 emissions, millions of tons from coal & IEA $^{1}$ \\
CO2 emissions from oil (Oil) & CO2 emissions, millions of tons from oil & IEA \\
CO2 emissions from natural gas (Gas) & CO2 emissions, millions of tons from natural gas & IEA \\
MSCI stock index (Stocks) & MSCI stock index (large and mid-cap) prices with & MSCI $^{2}$ \\
\hline
\end{tabular}

${ }^{1}$ IEA is the International Energy Agency; ${ }^{2} \mathrm{MSCI}$ is the Morgan Stanley Capital International World Index. 
Figure 1 presents the annual series of $\mathrm{CO} 2$ emissions from combusting coal (red line), oil (blue line), and gas (turquoise line). The 20 time series are from 1971 to 2017. The MSCI stock indices are presented in four groups, specifically: (1) World, Europe, USA, Canada and Australia; (2) Austria, Belgium, Denmark, Norway and Sweden; (3) France, Germany, Italy, Spain and UK; and (4) The Netherlands, Switzerland, Japan, Singapore and Hong Kong.
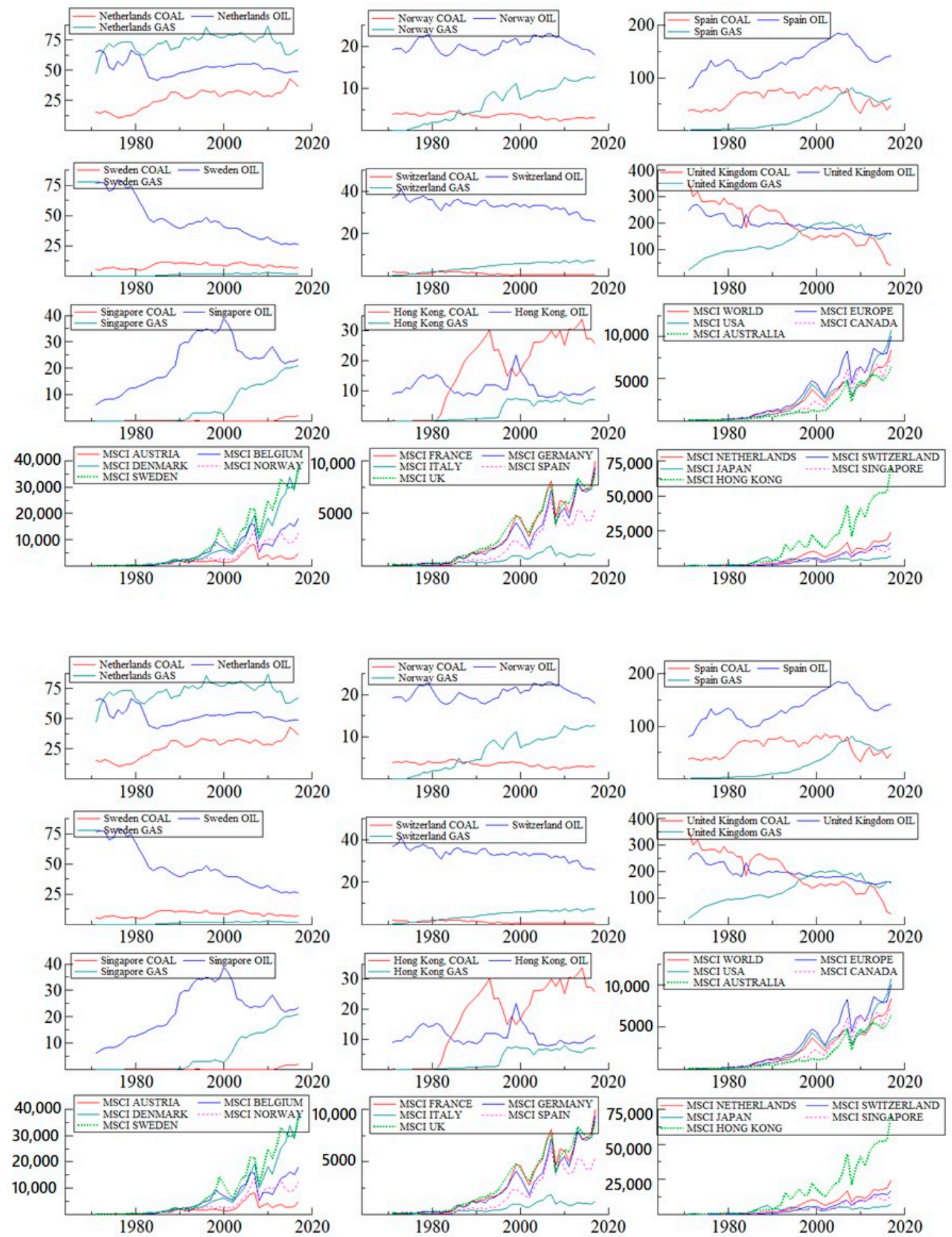

Figure 1. CO2 emissions from coal (red), oil (blue) and gas (turquoise) in 20 time series and MSCI stock indices for 1971-2017. 
According to the augmented Dickey-Fuller (ADF: [34] Dickey and Fuller, 1981) tests, based on including an intercept and a deterministic time trend (see Table 2), all the series in Figure 1 are found to be nonstationary with a unit root, while all the relative changes (or logarithmic returns) in emissions and MSCI returns are found to be stationary, where the relative changes in $\mathrm{CO} 2$ emissions are calculated as follows:

$$
R C_{t}=\ln \left(\frac{\mathrm{CO}_{2 t}}{\mathrm{CO}_{2 t-1}}\right)=\ln \mathrm{CO}_{2 t}-\ln \mathrm{CO}_{2 t-1}
$$

with $\mathrm{CO}_{2 t}\left(\mathrm{CO}_{2 t-1}\right)$ denoting annual carbon emissions in year $t(t-1)$. Siimlarly, the logarithmic returns in the MSCI stocks index are calculated as:

$$
r_{t}=\ln \left(\frac{P_{t}}{P_{t-1}}\right)=\ln P_{t}-\ln P_{t-1}
$$

with $P_{t}\left(P_{t-1}\right)$ denoting the MSCI index price (with dividends included) in year $t(t-1)$.

For these reasons, the empirical analysis will use the logarithmic returns of fuel combustion and the stock index.

Table 2. Augmented Dickey-Fuller (ADF) test for relative changes in CO2 emissions from coal, oil and gas, and MSCI stock returns.

\begin{tabular}{cllll}
\hline & Coal & Oil & Gas & Stocks \\
\hline World & $-4.05^{* *}$ & $-4.73^{* *}$ & $-8.15^{* *}$ & $-6.61^{* *}$ \\
Europe & $-6.09^{* *}$ & $-5.29^{* *}$ & $-6.12^{* *}$ & $-6.96^{* *}$ \\
USA & $-7.78^{* *}$ & $-4.84^{* *}$ & $-6.65^{* *}$ & $-6.26^{* *}$ \\
Canada & $-6.54^{* *}$ & $-4.47^{* *}$ & $-7.11^{* *}$ & $-8.02^{* *}$ \\
Australia & $-7.16^{* *}$ & $-5.19^{* *}$ & $-7.22^{* *}$ & $-8.70^{* *}$ \\
Japan & $-6.46^{* *}$ & $-5.25^{* *}$ & $-6.11^{* *}$ & $-6.35^{* *}$ \\
Austria & $-7.42^{* *}$ & $-6.46^{* *}$ & $-6.05^{* *}$ & $-6.13^{* *}$ \\
Belgium & $-10.51^{* *}$ & $-6.14^{* *}$ & $-7.88^{* *}$ & $-6.52^{* *}$ \\
Denmark & $-9.70^{* *}$ & $-4.95^{* *}$ & $-14.29^{* *}$ & $-9.54^{* *}$ \\
France & $-8.21^{* *}$ & $-5.82^{* *}$ & $-7.28^{* *}$ & $-6.68^{* *}$ \\
Germany & $-5.65^{* *}$ & $-6.77^{* *}$ & $-5.27^{* *}$ & $-7.15^{* *}$ \\
Italy & $-6.09^{* *}$ & $-5.72^{* *}$ & $-5.24^{* *}$ & $-5.66^{* *}$ \\
The Netherlands & $-4.88^{* *}$ & $-5.13^{* *}$ & $-7.47^{* *}$ & $-6.95^{* *}$ \\
Norway & $-7.84^{* *}$ & $-5.37^{* *}$ & $-9.64^{* *}$ & $-8.14^{* *}$ \\
Spain & $-7.47^{* *}$ & $-4.74^{* *}$ & $-6.64^{* *}$ & $-5.23^{* *}$ \\
Sweden & $-7.52^{* *}$ & $-5.49^{* *}$ & $-8.26^{* *}$ & $-7.18^{* *}$ \\
Switzerland & $-4.89^{* *}$ & $-8.57^{* *}$ & $-9.57^{* *}$ & $-7.00^{* *}$ \\
UK & $-5.61^{* *}$ & $-8.84^{* *}$ & $-6.26^{* *}$ & $-7.82^{* *}$ \\
Singapore & $-8.67^{* *}$ & $-4.97^{* *}$ & $-4.37^{* *}$ & $-8.64^{* *}$ \\
Hong Kong & $-3.71^{* *}$ & $-5.30^{* *}$ & $-5.76^{* *}$ & $-7.59^{* *}$ \\
\hline
\end{tabular}

${ }^{*}$ denotes significance at $5 \%$ (critical value -3.51$),{ }^{* *}$ denotes significance at $1 \%$ (critical value -4.17$)$.

\section{Empirical Results}

The correlations for 1971-2017, where the variables are the relative changes in CO2 emissions in coal, oil, and gas and stock, are shown in Tables 3-22.

Table 3. Correlations for World.

\begin{tabular}{ccccc}
\hline & Coal & Oil & Gas & Stocks \\
\hline Coal & 1 & & & \\
Oil & 0.243 & 1 & & \\
Gas & 0.4596 & 0.4766 & 1 & 1 \\
Stocks & 0.0487 & 0.0958 & -0.0461 & 1 \\
\hline
\end{tabular}


Table 4. Correlations for Europe.

\begin{tabular}{ccccc}
\hline & Coal & Oil & Gas & Stocks \\
\hline Coal & 1 & & & \\
Oil & 0.0485 & 1 & & \\
Gas & 0.0195 & 0.5492 & 1 & 1 \\
Stocks & 0.1059 & 0.0330 & -0.0371 & 1 \\
\hline
\end{tabular}

Table 5. Correlations for USA.

\begin{tabular}{ccccc}
\hline & Coal & Oil & Gas & Stocks \\
\hline Coal & 1 & & & \\
Oil & 0.3438 & 1 & & \\
Gas & 0.1186 & 0.2483 & 1 & 1 \\
Stocks & 0.0364 & 0.1899 & -0.0420 & 1 \\
\hline
\end{tabular}

Table 6. Correlations for Canada.

\begin{tabular}{ccccc}
\hline & Coal & Oil & Gas & Stocks \\
\hline Coal & 1 & & & \\
Oil & 0.0676 & 1 & & \\
Gas & 0.1681 & 0.3720 & 1 & 1 \\
Stocks & 0.0912 & 0.2073 & 0.0997 & 1 \\
\hline
\end{tabular}

Table 7. Correlations for Australia.

\begin{tabular}{ccccc}
\hline & Coal & Oil & Gas & Stocks \\
\hline Coal & 1 & & & \\
Oil & 0.0032 & 1 & & \\
Gas & 0.2688 & -0.0035 & 1 & \\
Stocks & 0.0552 & -0.3520 & -0.1066 & 1 \\
\hline
\end{tabular}

Table 8. Correlations for Japan.

\begin{tabular}{ccccc}
\hline & Coal & Oil & Gas & Stocks \\
\hline Coal & 1 & & & \\
Oil & 0.1299 & 1 & & \\
Gas & -0.0150 & 0.5225 & 1 & \\
Stocks & -0.1350 & 0.0441 & -0.0923 & 1 \\
\hline
\end{tabular}

Table 9. Correlations for Austria.

\begin{tabular}{ccccc}
\hline & Coal & Oil & Gas & Stocks \\
\hline Coal & 1 & & & \\
Oil & 0.0887 & 1 & & \\
Gas & 0.3428 & 0.4732 & 1 & 1 \\
Stocks & -0.0285 & 0.2813 & 0.2672 & 1 \\
\hline
\end{tabular}

Table 10. Correlations for Belgium.

\begin{tabular}{ccccc}
\hline & Coal & Oil & Gas & Stocks \\
\hline Coal & 1 & & & \\
Oil & 0.1015 & 1 & & \\
Gas & 0.2156 & 0.2031 & 1 & 1 \\
Stocks & -0.2191 & 0.2533 & 0.1045 & 1 \\
\hline
\end{tabular}


Table 11. Correlations for Denmark.

\begin{tabular}{ccccc}
\hline & Coal & Oil & Gas & Stocks \\
\hline Coal & 1 & & & \\
Oil & 0.2079 & 1 & & \\
Gas & 0.0610 & -0.2772 & 1 & 1 \\
Stocks & -0.0073 & 0.0725 & -0.2831 & 1 \\
\hline
\end{tabular}

Table 12. Correlations for France.

\begin{tabular}{ccccc}
\hline & Coal & Oil & Gas & Stocks \\
\hline Coal & 1 & & & \\
Oil & 0.1585 & 1 & & \\
Gas & 0.2851 & 0.4242 & 1 & \\
Stocks & 0.1017 & 0.2194 & 0.1323 & 1 \\
\hline
\end{tabular}

Table 13. Correlations for Germany.

\begin{tabular}{ccccc}
\hline & Coal & Oil & Gas & Stocks \\
\hline Coal & 1 & & & \\
Oil & -0.1738 & 1 & & \\
Gas & 0.1524 & 0.3802 & 1 & 1 \\
Stocks & 0.05302 & -0.0014 & -0.0077 & 1 \\
\hline
\end{tabular}

Table 14. Correlations for Italy.

\begin{tabular}{ccccc}
\hline & Coal & Oil & Gas & Stocks \\
\hline Coal & 1 & & & \\
Oil & 0.1147 & 1 & & \\
Gas & 0.1968 & 0.3520 & 1 & \\
Stocks & -0.1304 & 0.1008 & -0.1182 & 1 \\
\hline
\end{tabular}

Table 15. Correlations for The Netherlands.

\begin{tabular}{ccccc}
\hline & Coal & Oil & Gas & Stocks \\
\hline Coal & 1 & & & \\
Oil & -0.1012 & 1 & & \\
Gas & -0.2694 & 0.0392 & 1 & 1 \\
Stocks & -0.1188 & 0.0782 & 0.0852 & 1 \\
\hline
\end{tabular}

Table 16. Correlations for Norway.

\begin{tabular}{ccccc}
\hline & Coal & Oil & Gas & Stocks \\
\hline Coal & 1 & & & \\
Oil & -0.1153 & 1 & & \\
Gas & -0.2154 & 0.3007 & 1 & 1 \\
Stocks & 0.0619 & 0.3199 & 0.1121 & 1 \\
\hline
\end{tabular}

Table 17. Correlations for Spain.

\begin{tabular}{ccccc}
\hline & Coal & Oil & Gas & Stocks \\
\hline Coal & 1 & & & \\
Oil & -0.0797 & 1 & & \\
Gas & 0.0850 & 0.5076 & 1 & 1 \\
Stocks & -0.0749 & 0.0254 & 0.1115 & 1 \\
\hline
\end{tabular}


Table 18. Correlations for Sweden.

\begin{tabular}{ccccc}
\hline & Coal & Oil & Gas & Stocks \\
\hline Coal & 1 & & & \\
Oil & 0.0498 & 1 & & \\
Gas & -0.1380 & -0.0655 & 1 & 1 \\
Stocks & 0.0181 & 0.0430 & 0.0405 & 1 \\
\hline
\end{tabular}

Table 19. Correlations for Switzerland.

\begin{tabular}{ccccc}
\hline & Coal & Oil & Gas & Stocks \\
\hline Coal & 1 & & & \\
Oil & -0.2038 & 1 & & \\
Gas & -0.2288 & 0.0878 & 1 & 1 \\
Stocks & -0.2803 & 0.2868 & 0.0524 & 1 \\
\hline
\end{tabular}

Table 20. Correlations for UK.

\begin{tabular}{ccccc}
\hline & Coal & Oil & Gas & Stocks \\
\hline Coal & 1 & & & \\
Oil & -0.378 & 1 & & \\
Gas & -0.1333 & 0.1097 & 1 & 1 \\
Stocks & 0.1823 & -0.1606 & -0.1917 & 1 \\
\hline
\end{tabular}

Table 21. Correlations for Singapore.

\begin{tabular}{ccccc}
\hline & Coal & Oil & Gas & Stocks \\
\hline Coal & 1 & & & \\
Oil & -0.0019 & 1 & & \\
Gas & -0.0330 & -0.1178 & 1 & 1 \\
Stocks & -0.0884 & 0.0750 & 0.0231 & 1 \\
\hline
\end{tabular}

Table 22. Correlations for Hong Kong.

\begin{tabular}{ccccc}
\hline & Coal & Oil & Gas & Stocks \\
\hline Coal & 1 & & & \\
Oil & -0.1206 & 1 & & \\
Gas & -0.0374 & -0.1591 & 1 & 1 \\
Stocks & -0.2665 & 0.0537 & 0.0165 & 1 \\
\hline
\end{tabular}

Tables 3-22 present the correlation matrices of all the stationary logarithmic returns series. Tables reveal that, for coal combustion, the highest negative correlation between stock market returns and $\mathrm{CO} 2$ emissions is for Switzerland at -0.28 , while the highest positive correlation is for UK at 0.18 . For oil combustion, the highest negative correlation between MSCI and CO2 emissions is for Australia at -0.35 , while the highest positive correlation is for Norway at 0.32 . For gas combustion, the highest negative correlation between MSCI and CO2 emissions is for Denmark at -0.28 , while the highest positive correlation is for Austria at 0.27 .

The correlation coefficients in Tables 3-22 are unconditional, and represent the average values for the sample period, 1972-2017, as one year is lost in calculating the log-returns. The rolling window method reveals the evolution of the correlation coefficients, and can be calculated using the relative changes in emissions and MSCI returns from 1972 to 1981. The correlation coefficients are given as $\rho_{i j t}$, where $i$ rfeers to the relative change in fossil fuel (coal, oil and gas, respectively) emissions, $j$ refers to MSCI returns of country $j$, and $t$ refers to the period 1972-1981, whereby the window is rolled progressively one year ahead. 
Using the rolling window approach and data, for each pair, we obtain 37 coefficients for ten-year rolling window correlation coefficients. Figure 2 gives an illustration of the rolling window coefficients for the UK. The figure shows the evolution of the correlation coefficient between coal-origin CO2 emissions and stock returns in the UK approaches zero, which differ from the average sample unconditional correlations. Nevertheless, the correlation coefficients between both oil and gas CO2 emissions and stock returns are negative for 2008-2017, as are the unconditional correlations over the longer period, 1972-2017.
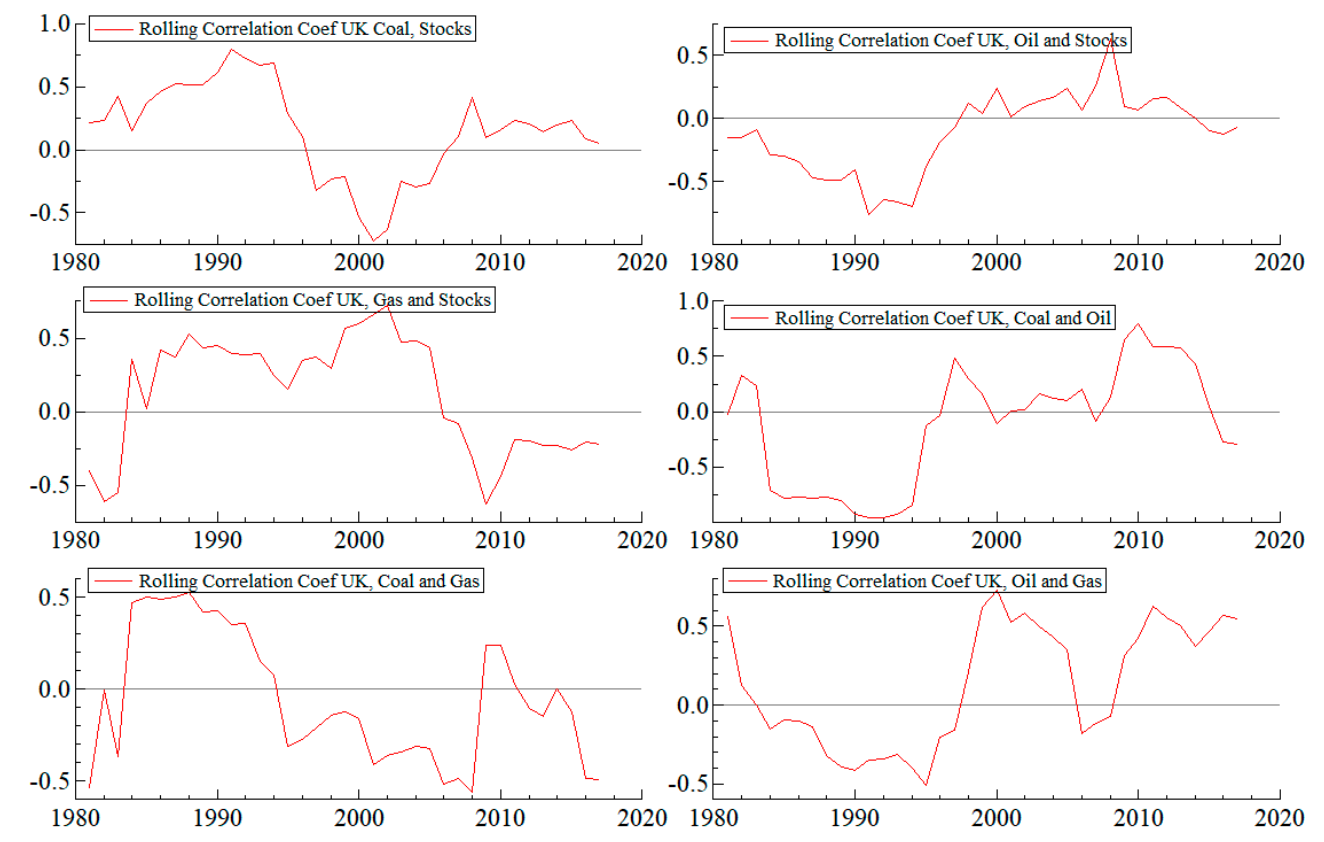

Figure 2. Ten-year rolling window correlations for the UK.

The rolling window correlations for UK are negative for all three fossil fuels, namely coal, oil and gas, for substantial subperiods of the full set of sample observations. Table 23 reports the last rolling window correlations between 2008 and 2017 for annual MSCI country index returns and annual relative changes in $\mathrm{CO} 2$ emissions from coal, oil and gas.

Table 23 reveals that the highest positive correlation between $\mathrm{CO} 2$ emissions from coal and stock returns is in Japan at 0.65 . This is probably because of the Fukushima nuclear disaster as the unconditional correlation in Table 8 is -0.14 . The highest negative correlation between stock returns and $\mathrm{CO} 2$ emissions is in Italy at -0.51 , and progress seems to have been climate friendly as the average correlation in Table 14 is -0.13 . The highest positive correlation between $\mathrm{CO} 2$ emissions from oil and stock returns is in Norway at 0.48 , which has increased from the unconditional correlation in Table 16 at 0.32 in the last subsample, 2008-2017.

The highest negative correlation for oil and stock returns is in Germany at -0.42 , indicating a positive development since the unconditional correlation in Table 13 is 0 . Furthermore, the highest positive correlation between $\mathrm{CO} 2$ emissions from gas combustion and stock returns is in Sweden at 0.62 , with a significant increase from the average correlation coefficient in Table 18 at 0.04 . The highest negative correlation between relative change in $\mathrm{CO} 2$ emissions from gas combustion and stock returns is in Spain at -0.52 , which is a substantial improvement from the unconditional correlation of 0.11 in Table 17.

Calculating the average correlation coefficients in Table 23 for the last subsample-2008-2017, in the European MSCI index countries (namely, Austria, Belgium, France, Denmark, Germany, Italy, The Netherlands, Norway, Spain, Sweden, Switzerland, and UK) produces the following average correlations between the pairs: stock returns and coal at -0.02 , stock returns and oil at -0.02 ; and stock returns and gas at 0.04 . The unconditional average correlations in Tables $9-20$ are $-0.03,0.12$ and 0.03 , 
respectively. Thus, there is a modest negative correlation between stock returns and CO2 emissions from oil combustion when the European Union Emissions Trading System (EU ETS) trading phases 2 and 3 have been active.

Table 23. Correlations from the last subsample (2008-2017).

\begin{tabular}{cccc}
\hline Country & Coal & Oil & Gas \\
\hline USA & 0.0064 & 0.4280 & -0.0074 \\
Canada & -0.1764 & 0.2323 & -0.1476 \\
Australia & 0.1471 & -0.3893 & 0.3359 \\
Japan & 0.6459 & 0.1114 & -0.2502 \\
Austria & -0.0675 & 0.3302 & 0.1224 \\
Belgium & -0.3628 & -0.2576 & 0.1445 \\
Denmark & -0.0703 & 0.0412 & 0.0487 \\
France & 0.3886 & -0.1406 & -0.0550 \\
Germany & 0.2688 & -0.4184 & 0.0502 \\
Italy & -0.5103 & -0.2965 & -0.0869 \\
The Netherlands & 0.0128 & -0.1964 & 0.0097 \\
Norway & -0.0983 & 0.4832 & 0.2484 \\
Spain & 0.0797 & -0.0670 & -0.5240 \\
Sweden & -0.1165 & 0.3202 & 0.6247 \\
Switzerland & 0.2465 & 0.0479 & 0.0691 \\
UK & 0.0516 & -0.0725 & -0.2210 \\
Singapore & 0.3322 & -0.0097 & 0.0369 \\
Hong Kong & 0.0532 & 0.2348 & -0.1813 \\
\hline
\end{tabular}

Table 24 presents the Granger causality test results where the null hypothesis is that the stock returns do not Granger-cause the relative change in $\mathrm{CO} 2$ emissions, or vice-versa, and the alternative hypotheses is that there is a unidirectional or bidirectional Granger-causal relationship. The null hypothesis is tested using a $5 \%$ significance level. The test statistic follows the $F$ distribution with $m$ and $n-k$ degrees of freedom:

$$
F=\frac{\left(R S S_{R}-R S S_{U}\right) / m}{R S S_{U} /(n-k)}
$$

where $m$ is the number of lagged variables in the restricted (null) regression, $n$ is number of observations for estimation and testing, $k$ is number of estimated parameters in the unrestricted (alternative) regression, $R S S_{R}$ is the residual sum of squares in the restricted (null) regression, and $R S S_{U}$ is the residual sum of squares in the unrestricted (alternative) regression.

The results in Table 24 show that all the statistically significant causality findings are unidirectional, where the stock market returns Granger-cause CO2 emissions, but not the reverse. If the causality test does not find statistically significant causality, the entries are given as "No causality". The sign $\rightarrow$ indicates unidirectional causality from one variable to another.

The outcomes of the causality tests are quite clear for the countries that are included in the [35] Morgan Stanley Capital International (MSCI) World Index (2020) from 1971 to 2017. Table 24 reports causality from stock returns to $\mathrm{CO} 2$ emissions from coal combustion for the USA, Austria, Belgium, Italy and Norway. In addition, Table 24 reports statistically significant causality from stock returns to $\mathrm{CO} 2$ emissions from oil combustion for the USA, Japan, The Netherlands, Spain and Singapore. Finally, the only significant causality from stock returns to $\mathrm{CO} 2$ emissions from gas combustion is identified as Spain. 
Table 24. Unidirectional granger causality results.

\begin{tabular}{cccc}
\hline Country & Coal & Oil & Gas \\
\hline USA & Stocks $\rightarrow$ Coal & Stocks $\rightarrow$ Oil & No causality \\
Canada & No causality & No causality & No causality \\
Australia & No causality & No causality & No causality \\
Japan & No causality & Stocks $\rightarrow$ Oil & No causality \\
Austria & Stocks $\rightarrow$ Coal & No causality & No causality \\
Belgium & Stocks $\rightarrow$ Coal & No causality & No causality \\
Denmark & No causality & No causality & No causality \\
France & No causality & No causality & No causality \\
Germany & No causality & No causality & No causality \\
Italy & Stocks $\rightarrow$ Coal & No causality & No causality \\
The Netherlands & No causality & Stocks $\rightarrow$ Oil & No causality \\
Norway & Stocks $\rightarrow$ Coal & No causality & No causality \\
Spain & No causality & Stocks $\rightarrow$ Oil & Stocks $\rightarrow$ Gas \\
Sweden & No causality & No causality & No causality \\
Switzerland & No causality & No causality & No causality \\
UK & No causality & No causality & No causality \\
Singapore & No causality & Stocks $\rightarrow$ Oil & No causality \\
Hong Kong & No causality & No causality & No causality \\
\hline & $\rightarrow$ indicates the direction of causality. &
\end{tabular}

The causality tests suggest that stock returns should explain relative changes in carbon emissions from coal and oil, but not gas. In order to detect this based on regression analysis, we use three linear regressions with dummy variables (LDV):

$$
\Delta \ln \text { CO2Emissions }_{i t}=\sum_{j=1}^{N} \alpha_{j} d_{i j}+\beta \times \text { returns }_{i t}+e_{i t}
$$

where $d_{i j}=1$ if $i=j$, and 0 otherwise. The dependent variable is the relative change of $\mathrm{CO} 2$ emissions from coal (the second regression is for oil, and the third regression is for gas) for country $i$, and the explanatory variable is stock returns in MSCI-world country $i$. Newey-West HAC (Heteroskedasticity and Auto-Correlation) robust standard errors are calculated.

Table 25 shows the panel regression results. The table reveals that, when stock returns rise by $1 \%$, emissions from coal are reduced by $9 \%$ at the $6.5 \%$ significance level. When stock returns rise by $1 \%$, emission from oil increases by $2 \%$ at the $0.1 \%$ significance level. When stock returns rise by $1 \%$, there are no significant effects of emissions on gas. Thus, it seems that positive stock returns reduce $\mathrm{CO} 2$ emissions from coal, but increases $\mathrm{CO} 2$ emissions from oil.

Table 25. Dummy variables (LDV) regression results of stock returns for coal, oil and gas.

\begin{tabular}{ccccc}
\hline Dependent Variable & Coefficient & HAC Standard Errors & Robust t-Value & Prob. Value \\
\hline Coal & -0.085 & 0.046 & -1.85 & 0.065 \\
Oil & 0.021 & 0.006 & 3.44 & 0.001 \\
Gas & -0.040 & 0.076 & 0.53 & 0.595 \\
\hline
\end{tabular}

\section{Concluding Remarks}

The international community seems to be generally agreeable that scientific evidence shows the use of fossil fuels, namely coal, oil and gas, as energy sources, leads to carbon dioxide (CO2) emissions, and hence to the destructive effects of global warming and climate change. It follows that mitigating the effects of global warming and climate change necessitates substantial reductions in the use of fossil fuel energy. 
This paper used a financial market-based approach to investigate whether positive stock returns cause changes in $\mathrm{CO} 2$ emissions based on the Granger causality test to determine cause and effect, or leader and follower. It was shown that if Granger causality could be determined in any direction, this would enable a clear directional statement to be made regarding temporal predictability between stock returns and $\mathrm{CO} 2$ emissions.

The empirical data included annual $\mathrm{CO} 2$ emissions from fuel combustion of the three main fossil energy sources, namely coal, oil and gas, based on 18 countries that are in the Morgan Stanley Capital International (MSCI) World Index from 1971 to 2017. The empirical results showed clearly that all the statistically significant causality findings were unidirectional from the stock market returns to $\mathrm{CO} 2$ emissions from coal, oil and gas, but not the reverse.

Therefore, as stock returns can affect carbon emissions, a financial-market based approach could be a useful addition to the variety of public and private policy armory considerations to mitigate the debilitating effects of carbon emissions on the global environment.

Specifically, for emissions from coal combustion, the results are encouraging as the market-oriented approach to deal with climate change requires a negative correlation between the variables. However, the results from oil reveal that positive stock returns have failed to reduce $\mathrm{CO} 2$ emissions suggesting that further research is required before any conclusive policy recommendations can be made.

Furthermore, the relationship between gas combustion and stock returns also needs more detailed investigation in order to suggest relevant policy recommendations. It may be that economic factors that affect the relationship between fossil energy emissions and stock returns have gradually changed over the last 50 years, but this needs more frequent data for greater precision. If the relationship has not developed gradually, the empirical results might suggest that we would need different regulations regarding coal and oil in order to mitigate the effects of global warming and climate change.

Author Contributions: All authors have read and agree to the published version of the manuscript. Conceptualization, M.M.; methodology, C.-L.C., J.I., H.L. and M.M.; software, J.I.; validation, C.-L.C., J.I., H.L. and M.M.; formal analysis, C.-L.C., J.I., H.L. and M.M.; investigation, C.-L.C., J.I., H.L. and M.M.; data curation, C.-L.C. and J.I.; writing—original draft preparation, M.M.; writing—review and editing, M.M.; visualization, C.-L.C., J.I. and H.L.; supervision, H.L. and M.M.; project administration, software, J.I.; validation, C.-L.C., J.I., H.L. and M.M.; formal analysis, C.-L.C., J.I., H.L. and M.M.; investigation, C.-L.C., J.I., H.L. and M.M.; data curation, C.-L.C.; funding acquisition, C.-L.C., J.I., H.L. and M.M.

Funding: This research received no external funding.

Acknowledgments: The very helpful comments of the editor and three reviewers are gratefully acknowledged. The first author wishes to thank the Ministry of Science and Technology (MOST), Taiwan, for financial support; the fourth author acknowledges the financial support of the Australian Research Council and the Ministry of Science and Technology (MOST), Taiwan.

Conflicts of Interest: The authors declare no conflict of interest.

\section{References}

1. McCollum, D.; Zhou, W.; Bertram, C.; de Boer, H.; Bosetti, V.; Busch, S.; Despres, J.; Drouet, L.; Emmerling, J.; Fay, M.; et al. Energy investment needs fulfilling the Paris Agreement and achieving the sustainable development goals. Nat. Energy 2018, 3, 589-599. [CrossRef]

2. Paris Agreement; Decision 1/CP.17; UNFCCC: New York, NY, USA, 2015.

3. McCollum, D.; Jewell, J.; Krey, V.; Bazilian, M.; Fay, M.; Raihi, K. Quantifying uncertainties influencing the long-term impacts of oil prices on energy markets and carbon emissions. Nat. Energy 2016, 1, 1-8. [CrossRef]

4. Staples, M.; Malina, S.; Barrett, S. The limits of bioenergy for mitigating global life-cycle greenhouse gas emissions from fossil fuels. Nat. Energy 2017, 2, 1-8. [CrossRef]

5. Sadorsky, P. The impact of financial development on energy consumption in emerging economies. Energy Policy 2010, 38, 2528-2535. [CrossRef]

6. Lau, L.-S.; Choong, C.-K.; Eng, Y.-K. Investigation of the environmental Kuznets curve for carbon emissions in Malaysia: Do foreign direct investment and trade matter? Energy Policy 2014, 68, 490-497. [CrossRef] 
7. Pao, H.-T.; Tsai, C.-M. Multivariate Granger causality between $\mathrm{CO}_{2}$ emissions, energy consumption, FDI (foreign direct investment) and GDP (gross domestic product): Evidence from a panel of BRIC (Brazil, Russian Federation, India and China) countries. Energy 2011, 36, 685-693. [CrossRef]

8. Seker, F.; Ertugrul, H.; Cetin, M. The impact of foreign direct investment on environmental quality: A bounds testing and causality analysis for Turkey. Renew. Sustain. Energy Rev. 2015, 52, 347-356. [CrossRef]

9. Paramati, S.; Mo, D.; Gupta, R. The effects of stock market growth and renewable energy use on $\mathrm{CO}_{2}$ emissions: Evidence from G20 countries. Energy Econ. 2017, 66, 360-371. [CrossRef]

10. Brockway, P.; Owen, A.; Brand-Correa, L.; Hardt, L. Estimation of global final-stage energy-return-on-investment for fossil fuels with comparison to renewable energy sources. Nat. Energy 2019, 4, 612-621. [CrossRef]

11. Egli, F.; Steffen, B.; Schmidt, T. A dynamic analysis of financing conditions for renewable energy technologies. Nat. Energy 2018, 3, 1084-1092. [CrossRef]

12. King, L.; van den Bergh, J. Implications of net energy-return-on-investment for a low-carbon energy transition. Nat. Energy 2018, 3, 334-340. [CrossRef]

13. Wilson, I.; Saffell, I. Rapid fuel switching from coal to natural gas through effective carbon pricing. Nat. Energy 2018, 3, 365-372. [CrossRef]

14. Rinscheid, A.; Wustenhagen, R. Germany's decision to phase out coal by 2038 lags behind citizens' timing preferences. Nat. Energy 2019, 4, 856-863. [CrossRef]

15. Granger, C. Investigating causal relations by econometric models and cross-spectral methods. Econometrica 1969, 37, 424-438. [CrossRef]

16. Granger, C. Testing for causality: A personal viewpoint. J. Econ. Dyn. Control 1980, 2, 329-352. [CrossRef]

17. Shahbaz, M.; Solarin, S.; Mahmood, H.; Arouri, M. Does financial development reduce $\mathrm{CO}_{2}$ emissions in Malaysian economy? A time series analysis. Econ. Model. 2013, 35, 145-152. [CrossRef]

18. Omri, A. $\mathrm{CO}_{2}$ emissions, energy consumption and economic growth nexus in MENA countries: Evidence from simultaneous equations models. Energy Econ. 2013, 40, 657-664. [CrossRef]

19. Ren, S.; Yuan, B.; Ma, X.; Chen, X. International trade, FDI (foreign direct investment) and embodied CO2 emissions: A case study of China industrial sectors. China Econ. Rev. 2014, 28, 123-134. [CrossRef]

20. Su, Y.; Chen, X.; Li, Y.; Liao, J.; Ye, Y.; Zhang, H. China's 19-year city-level carbon emissions of energy consumptions, driving forces and regionalized mitigation guidelines. Renew. Sustain. Energy Rev. 2014, 35, 231-243. [CrossRef]

21. $\mathrm{Xu}, \mathrm{H}$.; $\mathrm{Li}, \mathrm{Y}$;; Huang, $\mathrm{H}$. Spatial research on the effect of financial structure on $\mathrm{CO}_{2}$ emission. In Proceedings of the 2nd International Conference on Advances on Clean Energy Research, ICAER 2017, Berlin, Germany, 7-9 April 2017.

22. Zhao, B.; Yang, W. Does financial development influence $\mathrm{CO}_{2}$ emissions? A Chinese province-level study. Energy 2020, 200, 117523. [CrossRef]

23. Tamazian, A.; Chousa, J.; Vadlamannati, K. Does higher economic and financial development lead to environmental degradation: Evidence from BRIC countries. Energy Policy 2009, 37, 246-253. [CrossRef]

24. Jalil, A.; Feridun, M. The impact of growth, energy and financial development on the environment in China: A cointegration analysis. Energy Econ. 2011, 33, 284-291. [CrossRef]

25. Zhang, Y.J. The impact of financial development on carbon emissions: An empirical analysis in China. Energy Policy 2011, 39, 2197-21203. [CrossRef]

26. Ozturk, I.; Acaravci, A. The long-run and causal analysis of energy, growth, openness and financial development on carbon emissions in Turkey. Energy Econ. 2013, 36, 262-267. [CrossRef]

27. Haseeb, A.; Xia, E.; Baloch, M.A.; Abbas, K. Financial development, globalization, and $\mathrm{CO}_{2}$ emission in the presence of EKC: Evidence from BRICS countries. Environ. Sci. Pollut. Res. 2018, 25, 31283-31296. [CrossRef]

28. Ahmad, M.; Khan, Z.U.; Rahman, Z.; Khan, S. Does financial development asymmetrically affect $\mathrm{CO}_{2}$ emissions in China? An application of the nonlinear autoregressive distributed lag (NARDL) model. Carbon Manag. 2018, 9, 631-644. [CrossRef]

29. Boutabba, M.A. The impact of financial development, income, energy and trade on carbon emissions: Evidence from the Indian economy. Econ. Model. 2014, 40, 33-41. [CrossRef]

30. Xiong, L.; Tu, Z.; Ju, L. Reconciling regional differences in financial development and carbon emissions: A dynamic panel data approach. Energy Procedia 2017, 105, 2989-2995. [CrossRef] 
31. Huang, L.; Zhao, X. Impact of financial development on trade-embodied carbon dioxide emissions: Evidence from 30 provinces in China. J. Clean. Prod. 2018, 198, 721-736. [CrossRef]

32. Ziaei, S. Effects of financial development indicators on energy consumption and CO2 emission of European, East Asian and Oceania countries. Renew. Sustain. Energy Rev. 2015, 42, 752-759. [CrossRef]

33. International Energy Agency (IEA). 2020. Available online: www.iea.org (accessed on 1 March 2020).

34. Dickey, D.; Fuller, W. Likelihood ratio statistics for autoregressive time series with a unit root. Econometrica 1981, 49, 1057-1072. [CrossRef]

35. Morgan Stanley Capital International (MSCI). 2020. Available online: www.msci.com (accessed on 1 March 2020).

(C) 2020 by the authors. Licensee MDPI, Basel, Switzerland. This article is an open access article distributed under the terms and conditions of the Creative Commons Attribution (CC BY) license (http://creativecommons.org/licenses/by/4.0/). 